\title{
Rebellion, Rascals, and Revenue: Tax Follies and Wisdom through the Ages
}

MICHAEL KEEN and JOEL SLEMROD

Princeton University Press, 2021, pp. 511

Book review by DUBRAVKO MIHALJEK*

https://doi.org/10.3326/pse.46.1.6

${ }^{* *}$ Received: January 31,2022
Accepted: February 1,2022

Dubravko MIHALJEK, Ph.D.

Bank for International Settlements, Centralbahnplatz 2, 4002 Basel, Switzerland e-mail: Dubravko.Mihaljek@bis.org

ORCiD: 0000-0003-4706-9534 
Behind the unusual title of this book lies a remarkable scholarly work on taxation. Michael Keen and Joel Slemrod argue convincingly that taxation is a quintessential feature of every society - as de Tocqueville (1886) put it in his account of pre-revolutionary France, "There is scarcely any public matter that does not arise from a tax or end in one" (p. 4). For ordinary people, taxation is the way in which government encroaches on their lives most directly. For rulers and governments, the way they tax largely determines whether and how they stay in power.

This is where rebellion and rascals come in. Throughout history, tax measures have been one of the tipping points sparking conflict over the ways sovereign powers are being exercised or allocated. A recent example is the gilets jaunes movement in France, prompted by a fuel tax increase but generally seen as reflecting a wider anger at a government that is perceived to be governing for the benefit of the better-off, Paris-based elite (p. 376). And as one of the most salient manifestations of the state's coercive power, taxes have often invited rascality. A young Richard Branson, for instance, falsely claimed that his Virgin label exported 30,000 records so that he would not pay a tax on their sales (p. 286).

The authors describe their book as a "museum of tax curiousae": a collection of historical examples of tax wisdom and folly, i.e., taxes that do and do not make sense in economic and practical terms. The curators' aim for this museum is humble: "to bring a little more wisdom to the future of taxation" (p. xix). The outcome is far more impressive. Many examples that Keen and Slemrod bring to light will be near impossible to forget. The narrative is rich, erudite, insightful, engaging and entertaining. There is something for everyone to learn from this colourful history of taxation.

The book is organised in five parts, each with a revealing title. Part I, "Plunder and Power", is a broad-strokes review of the history of taxation, from ancient Sumerian and Egyptian civilisations all the way to modernity. Its conclusion - setting the tone for the rest of the book - is that governments have been remarkably adept and creative in financing themselves over the millennia. While methods of taxation have changed, the fundamental challenges have remained largely unaltered: how to raise revenue without causing too much collateral damage to the economy, how to ensure that taxes are perceived as fair enough for the regime to survive, and how actually to collect the taxes.

Part II, "Winners and Losers", provides lessons from history for two critical issues in taxation: what makes a tax "fair", and who really bears the burden of taxation. Chapter 4 highlights the evolution of thinking on different dimensions of fairness in taxation. One notable historical example is the poll tax. The first well documented case of such a tax dates back to England after the bubonic plague pandemic in 1377. At the time, the tax met with little opposition: it was levied at a low rate on all adults over 14; it had to be paid by the clergy, who were previously exempt from all taxes; richer households in a community were expected to pay 
more to aid the poorer ones. However, when the tax was tripled in 1381, a major uprising - the Peasants' Revolt - ensued.

Six centuries later, the Margaret Thatcher government seemed to have forgotten this historical episode. In 1990, it introduced a "community charge", a head tax that required every adult to pay a fixed amount set by local authority. The government argued that local spending was financed mostly by landlords, while tenants mostly benefited from and voted on it. Consistent with the principle that "everyone should contribute something and therefore have something to lose from electing a spendthrift council", only prisoners were exempt (p. 90). The tax rules, however, established no clear relationship with local income levels. Residents of some of the poorest neighbourhoods in London were asked to pay up to one third more than those of the richest boroughs. In addition, the tax was assessed on out-of-date rental values that did not account for the higher property price inflation in more affluent areas. The tax was opposed by $78 \%$ of the population and culminated in a full-blown riot in London on 31 March. It was abolished a few months after Mrs Thatcher's resignation in November 1990, and replaced by a council tax similar to the one used before 1990 .

No less insightful is the review of the emergence of the modern income tax - "this colossal engine of finance" (Chapter 5), of the perils of ignoring horizontal equity issues in taxation (Chapter 6), and the question of who bears the burden of taxation (Chapter 7). For instance, Keen and Slemrod identify some common traps in tax incidence analysis. One is to presume that the name of a tax has anything to do with where the burden it imposes ultimately falls. A prominent example is the now discontinued World Bank's Doing Business survey: it counted as businessunfriendly the employer's - but not the employee's - social security contribution. This apparently led some governments to shift the contribution notionally from employers to employees while leaving the total unchanged - an easy but essentially meaningless way to get a better business friendliness score, given that both parts of the contribution are levied on wage income (p. 151). Similar traps in thinking about tax incidence inhere in ascribing too much importance to where the legal liability for remitting a tax lies - e.g., on whether the buyer or the seller of property remits the transaction tax to authorities; or to suppose that incidence is something that can be fixed by tax rules - e.g., the U.S. retailers' practice of displaying prices of goods and services without including the state sales tax.

The upshot of these examples is that tax incidence depends on the relative responsiveness of demand and supply, and on the presence of any rents. It is the people with fewest alternatives that tend to get stuck with most of the tax burden in the short run, though not necessarily in the long run. Particularly murky is the incidence of corporate income tax. Unfortunately, academic work does not help shed much light on the question of whether workers or capital owners bear the brunt of the corporate tax. A survey conducted for the U.S. Congress (Gravelle, 2017) found that studies it looked at were "seriously flawed, produced unreasonable 
estimates, were not robust, or were inconsistent with theory" (p. 166). There is more agreement among key U.S. policy analysis institutions, however: they established that in the long run around one quarter of the burden of corporate tax falls on labour, and three quarters on owners of capital.

Part III, "Changing Our Ways", looks at further aspects of tax design: how various tax rules affect the behaviour of taxpayers; the economic and social consequences of taxpayers' responses; and how these responses shape redesign of tax rules. Chapter 8 discusses examples of the "corrective" use of taxes, i.e., taxes partly aimed at discouraging or encouraging certain types of behaviour. The former include such weird examples as a 1698 tax on beards in Russia - an effort by Peter the Great to modernise the look of the Russian nobility - and a 1928 tax on bobbed hairstyles for women in the Swiss canton of Uri. The bulk of the chapter deals with taxation of more mainstream "bads" such as tobacco, alcohol and carbon emissions. Interestingly, Keen and Slemrod could find no examples of taxes targeted to rock and roll or any other kind of music. I am therefore pleased to offer an exhibit for their museum of tax curiosae: the authorities in Vienna passed in 1821 a Musik Impost ordinance charging fees differentiated by type of music and time of performance. These included a fee per musician performing in private homes of Viennese families, and higher imposts after midnight or during carnival season (Hanson, 1985: 152-154). Think of Franz Schubert playing his latest piano sonatas at a private soirée and uniformed guards collecting music taxes from the host.

In Chapter 9, Keen and Slemrod provide some memorable examples of distortions in behaviour and associated damage that taxes can induce. For nearly a century after 1773, British ships were charged port and lighthouse fees by a formula that provided incentives to build long ships with narrow decks and deep holds. Ships of such design maximised cargo capacity while minimising taxes - but they could not sail well with the wind in different directions. Another tax curiosity is the property tax based on the width of the street-facing façade of houses. This rule resulted in the construction of narrow, elongated houses, whose layout affected everyday life patterns of tenants for generations. Similarly, taxes on windows and fireplaces resulted in countless $17^{\text {th }}$ century families in England spending much of their daily life in relative darkness and cold. Closer to our time, corporations face a stark choice between the tax treatment of two basic ways to raise finance, i.e., debt and equity, with the tax code almost everywhere favouring debt finance. This bias has partly contributed to a steady stream of bankruptcies of over-indebted non-financial corporations, including Enron in the United States, Parmalat in Italy, and Evergrande in China (one could also add Agrokor in Croatia). Or, even worse, of over-indebted banks, as the protracted recovery from the Great Financial Crisis has shown.

Chapter 10 takes a broader look at tax design at the national level: the trade-off between efficiency and equity at the level of individual taxes and their interactions. The evocative title, "How to Pluck a Goose", starts with a memorable quote of 
Jean-Baptiste Colbert, the First Minister of State to King Louis XIV: "The art of taxation consists in so plucking a goose as to obtain the largest possible amount of feathers with the smallest amount of hissing" (p. 225). "Hissing" refers of course to the excess burden and unfairness of a tax, the concepts that Colbert and his predecessors understood very well without the analytical apparatus of modern public finance. This chapter comes closest to a standard textbook treatment of optimal taxation. It explains in intuitive ways the economics of excess burden, lump sum taxes, rents, corporate profit shifting, tax on the unimproved value of land, wealth taxes, time inconsistency, VAT, financial transactions taxes, Ramsey's optimal consumption taxes, and Diamond and Mirrlees' optimal income taxes.

While the principles of optimal taxation have improved our understanding of tax design at the national level, they assume away the issues that arise when tax effects spill across national borders. This is problematic because, as Keen and Slemrod note, tax sovereignty is a thing of the past - the real question today is how countries choose to pool and exercise the collective sovereignty that they still possess (p. 279). Chapter 11 discusses tax avoidance practices and authorities' counter-measures in the area of international taxation, using examples ranging from ancient Greece and Rome to the U.S. Foreign Account Tax Compliance Act of 2014. For instance, when the Emperor Diocletian found that, rather than paying taxes, many small farmers holding marginal land were abandoning their plots, he made sure that those moving away remained liable for the tax due on their land (p. 263). Similarly, U.S. citizens today have to pay income tax on all their income, wherever they are resident, although with a credit for taxes paid outside the United States.

Particularly instructive is the discussion of transfer pricing used by multinational companies; the work of the League of Nations in the 1920s that established two core principles of corporate taxation for multinationals used to this day (i.e., "armslength" transfer pricing and physical presence); and the proposal for a destinationbased cash flow tax (DBCFT), elaborated among others by Auerbach and Devereux (2013) and proposed in the U.S. Congress in 2016. The latter would have mimicked a VAT in the corporate tax space. By excluding exports, taxing imports (but deducting the tax for businesses), and allowing immediate deductibility of all investment and wage costs, the DBCFT would have largely removed the rationale for transfer pricing and relocation of production solely for tax purposes, and would have acted as a rent tax. Keen and Slemrod acknowledge, however, that despite these desirable properties, the time for such a tax has not yet come.

The book was published before the landmark international agreement on Base Erosion and Profit Sharing (BEPS) reached in November 2021. The BEPS package, led by the OECD and the G20, provides countries with a dozen or so tools to ensure that profits are taxed where economic activities generating the profits are performed and where value is created. These tools also give businesses greater certainty by reducing disputes over the application of international tax rules and standardising compliance requirements. It will be interesting to follow 
discussions comparing the BEPS package with the destination-based cash flow tax. What is encouraging, as noted by Keen and Slemrod, is that the OECD, "long the sometimes-abrasive defender of both of the two core norms of international taxation, has effectively conceded that both may have outlived their time" (p. 275).

The other key element assumed away in the optimal taxation literature is tax collection. Keen and Slemrod turn to this issue in Part IV, aptly entitled "Taxes Don't Collect Themselves". The main arguments they advance is that compulsion remains key to tax enforcement, and that a tax administration's core job is to shape taxpayers' incentives in such a way that they comply. A "good equilibrium" is a situation in which most people comply because others do as well. A "bad equilibrium" is the one in which the poor compliance of some taxpayers reduces that of others. While technology plays an important role in improving tax compliance, it does not solve the fundamental problem of tax collectors - catching up with tax avoidance schemes devised by taxpayers. To illustrate these points, the authors describe a gallery of tax rascals and tax collectors through history, together with tools they used. I found particularly illuminating the historical accounts of tax farming and income tax withholding, which are hard to find in contemporary public finance books.

Somewhat hidden in the chapter is the notion that tax compliance also depends on taxpayers' acceptance of the entire tax and public expenditure systems as reasonable. Nordic countries, for example, are believed to have relatively good tax compliance partly because of public provision of labour complements such as child and elderly care, transportation, and education (Jacobsen Kleven, 2014), and Switzerland because citizens have direct control of government budgets (Pommerehne and Weck-Hannemann, 1996). Keen and Slemrod return to some of these issues in the last chapter of the book, where they note that a strong tax system is built on mutual and reinforcing trust, including "enabling tax administrators to treat taxpayers as something more than latent criminals" (p. 386).

The last part of the book, "Making Taxes", looks at the legislative process behind tax rules and summarises the authors' views on the key lessons from history and on future challenges for taxation. Chapter 14 on the making of tax rules is depressing reading: it suggests that most tax reforms are watered down and rendered less effective through intense lobbying of special interest groups. The examples used are convincing, but mostly refer to U.S. and UK experiences. Many countries in continental Europe, however, operate income tax systems with relatively few tax exemptions and deductions (e.g., Switzerland), or with only one or two rates and very few exemptions from VAT (Denmark, Germany, the Netherlands). That said, Keen and Slemrod do note that in Germany, for instance, tax measures that benefit particular groups are prohibited by the Constitution. And they describe the U.S. Tax Reform Act of 1986 as an example of successful income tax reform. Importantly, they highlight the rise of the VAT as the global success story of tax reform 
in the past half century. Value added tax, raising about $30 \%$ of the world's tax revenue, has provided over 160 countries with a clear vision of what a better tax system looks like.

The book concludes with 11 "pillars of tax wisdom", "lessons that millennia of enduring, arguing and thinking about taxation teach us" (p. 375). I leave these eloquent summaries for readers themselves to discover. The very last section "The Future and Beyond" - serves as a kind of coda to some themes developed in the book. These include the challenges of increased mobility of tax bases, harnessing of big data and digital technologies to improve the effectiveness of tax administration, the future of corporation tax, taxation on a lifetime instead of an annual basis, and how advances in genetic information might affect our thinking about vertical and horizontal equity. All in all, a must read for anyone interested in public finance. 


\section{REFERENCES}

1. Auerbach, A. and Devereux, M., 2013. Consumption and cash-flow taxes in an international Setting. NBER Working Paper, No. 19579. https://doi. org/10.3386/w19579

2. De Tocqueville, A., 1866. L'Ancien Régime et la Révolution. $7^{\text {th }}$ edition. Paris: Michel Lévy Frères.

3. Gravelle, J. G., 2017. Corporate tax reform: issues for Congress. Congressional Research Service Report. Washington, DC, 22 September 2017.

4. Hanson, A. M., 1985. Musical Life in Biedermeier Vienna. Cambridge: Cambridge University Press.

5. Jacobsen Kleven, H., 2014. How can Scandinavians tax so much? Journal of Economic Perspectives, 28, pp. 77-98. https://doi.org/10.1257/jep.28.4.77

6. Pommerehne, W. W. and Weck-Hannemann, H., 1996. Tax rates, tax administration and income tax evasion in Switzerland. Public Choice, 88, pp. 161-170. https://doi.org/10.1007/BF00130416 